\title{
The Potential and Pitfalls of Peace Education: A Cultural Political Economy Analysis of the Emerging Issues Teacher Education Curriculum in Sierra Leone
}

\author{
Sean Higgins and Mario Novelli
}

\begin{abstract}
Peace education in conflict affected societies has achieved widespread popularity amongst international aid agencies seeking to find a place for education in supporting peacebuilding since the 1990s. However, its aims, content, and effectiveness have been critiqued particularly for its failures to address structural causes of grievances. This article draws on empirical research exploring a UNICEF supported peace education related curriculum reform in Sierra Leone developed in 2008 called "Emerging Issues." The article draws on a critical discourse analysis of its content and qualitative interview data with key informants. It argues that while "Emerging Issues" was well-intentioned, its lack of regard for contextual dynamics generating conflict and a tendency to pathologize the nation served to undermine its transformatory goals.
\end{abstract}

Keywords peace education, Sierra Leone, peacebuilding, cultural political economy

\section{Introduction}

Peace education, aiming to promote attitudinal and behavioural change in conflict affected societies, has achieved widespread popularity amongst international aid agencies seeking to find a place for the role of education in supporting peacebuilding since the 1990s (UNESCO 2011, 245). As an intervention developed by international aid agencies for implementation by teachers in diverse conflict affected contexts, it has been very influential in framing their expected agency in such settings. Teachers' contribution to peacebuilding is therefore frequently aligned with a psycho-social process of conflict amelioration through changing the hearts, minds, values, and behaviors of pupils, their families, and wider communities in order to enhance their capacity to forge more harmonious inter-personal relationships (Sinclair 2004; Novelli and Sayed 2016). 
However, the aims, content, and effectiveness of such peace education interventions have been also critiqued by scholars pointing in particular to their failures to address structural causes of grievance and a lack of reflexivity about its underlying assumptions and implications for the roles of teachers (Novelli and Sayed 2016, 34; Zembylas and Beckerman 2013). Responding to such contrasting views, this article draws on empirical research on a United Nations Children's Fund (UNICEF) supported peace education related curriculum reform in Sierra Leone developed in 2007/2008 for in-service and pre-service teachers called "Emerging Issues" (Novelli 2011, 54). This was developed through a collaboration with lecturers at the country's teacher education colleges as well as international peace education consultants. As a flagship product of the United Nations (UN) Peacebuilding Programme in Sierra Leone, and adopted as an exemplary model of peace education by the International Network for Education in Emergencies (INEE), this curriculum is particularly appropriate as the focus of a case study on peace education. While addressing four thematic areas of civics and democracy, gender, health and environment, and human rights, as well as offering learner centred pedagogy, the curriculum was explicitly framed following the priorities of peace education "as a way of creating a composite and comprehensive whole for the dimension of personal behaviour change" (Baxter 2012, 175). Highlighting its exemplary status as a peace education curriculum modelled on earlier versions, "Emerging Issues" has been described as "probably the best example of the INEE (peace education) programme being used as a 'Mother' manual" (ibid., 176).

This article takes this curriculum as a case study through which to explore both the potential as well as the pitfalls of this type of educational intervention in a specific conflict affected context. It focuses on its production and textual content. It interrogates the curriculum's underlying assumptions about peacebuilding processes, the needs and agency of conflict affected Sierra Leoneans, the drivers of conflict in the country, and the agency of teachers. The article aims to make a distinctive contribution to recent critical reflection on the nature and effectiveness of peace education (Zembylas and Bekerman 2013) by drawing on some of the tools of social analysis offered by cultural political economy, hereafter CPE (Sum and Jessop 2013). This is a recently developed trans-disciplinary approach to the analysis of the social world which explores the interconnections between the dimension of the cultural-understood as systems of meaning making through which the social world is apprehended and understood-with the traditional concerns of political economy analysis with power relationships and the role of institutions. Of particular relevance is the resulting analytical attention of $\mathrm{CPE}$ to the partial and contingent nature of all representations of the social world, which are thereby understood as outcomes of their embeddedness in political economy processes through which some versions are privileged over others. In this way, what Sum and Jessop (ibid.) call "common sense assumptions" that may frame the actions and understandings of agents in 
the social world are denaturalized and subject to critical explanation within CPE analysis. Given what some have seen as an overly idealistic commitment to peace education as a benign panacea for conflict affected communities, this approach offers a compelling framework to enable such curricula to be subjected to greater critique and scrutiny.

This article's critical approach to peace education also responds to insights emerging from recent research on the contribution of teachers, education systems, processes, and, more broadly, to sustainable peacebuilding in conflict affected contexts (Novelli and Sayed 2016). Firstly, this has drawn attention to the relevance of "high quality...conflict analysis that is sensitive to the conflict dynamics of local contexts" (Novelli and Smith 2011, 7). This is necessary to maximize the contribution of education to peacebuilding by ensuring that programming goes beyond a generic faith in the positive value of all educational interventions (ibid., 24) and to ensure a precise orientation to conflict drivers. Second, this research (Novelli et al. 2016) has illuminated the potential of education to contribute to transformatory peace by addressing structural drivers of conflict and contributing to processes of social justice outlined by the philosopher and social theorist Nancy Fraser (2005). Education interventions in conflict affected contexts are therefore recognized as potentially contributing to political processes of representation, economic processes of redistribution of resources and opportunities, and cultural processes of recognition of ethnic or religious identities that may address grievances driving conflict. By leveraging changes within these systemic processes, education potentially has a pivotal role in building what Galtung has characterized as a form of "positive" rather than "negative peace" (Dilts et al. 2012, 191). In simple terms, this implies that education needs to contribute not only to the cessation of violence, but also to addressing the structural inequalities that underpin conflicts.

Thirdly, while highlighting new criteria through which to understand the transformative potential of education, these insights throw into relief the limited priority given to social services provision within the dominant forms of international interventionism in conflict affected contexts known as liberal peacebuilding (Novelli and Smith 2011). Privileging issues of security and the opening up of markets, this model of peacebuilding has arguably underestimated education "as a core component of building sustainable peace" (ibid., 7). Recent research by a number of scholars highlights the failures of this model in Sierra Leone, drawing attention to the "violence" of the peace experienced by the majority of its population and indeed the continuance of many drivers that caused conflict (Castañeda 2009; Cubitt 2011, 2013; Drew and Ramsbotham 2012; Novelli and Higgins 2017).

Fourthly and of particular relevance to the concerns of this article are the implications of these insights for understanding the agency of teachers. Within such conceptualizations of the relationship between education and peacebuilding, 
they are positioned not only as contributors to intra-personal and inter-personal changes in the attitudes and behaviors of conflict affected communities, but also to transformations of the structural social, political, and economic dynamics that impinge on them. In this light, Sayed and Novelli $(2016,14)$ have called for a widened understanding of teacher agency to "encompass strategies in and through teaching which confront the historic inequities and drivers of conflict." This article draws on such insights to analyze the framing of teacher agency within peace education curricula.

Finally, this is an opportune moment to review existing educational interventions in conflict affected contexts given the renewed international attention to the role of education and teachers in promoting peaceful and inclusive societies in the Sustainable Development Goals. Clarifying a "New Agenda for Education in Fragile States," Winthrop and Matsui $(2013,1)$ urge academics and practitioners alike to "take stock" of the strengths and weaknesses of educational interventions implemented since the emergence of a specialized field of practice and research into education and peacebuilding in the 1990s. This will enable educationists to make a persuasive case for the role of education in the global conversations involving security, humanitarian, and education actors currently available at this conjuncture in its evolution.

The article therefore starts by providing a historical perspective on the emergence of peace education in the late 1990s, together with a review of recent critical commentary. This locates the article's case study within current issues and debates on its content and impact. Second, the distinctive characteristics of a cultural political economy approach (CPE) are outlined with attention to its usefulness in the critique, analysis, and interpretation of peace education curricula. This section also outlines the article's research design and methodology based on the analytical priorities opened up by this theoretical positioning. The third section sets the context for the case study by reviewing the nature of Sierra Leone's conflict between 1992 and 2002 and its post conflict trajectory since peace accords were agreed upon in 2002. The fourth section presents the findings of the analysis of the curriculum's content and processes of development. The final section reflects more broadly on the insights of the case study, pointing to some of the pitfalls of this model of intervention as highlighted through a CPE analysis.

\section{Peace Education Revisited: Issues and Critiques}

In a seminal work on the contribution of education to "reshaping the future" of societies during post-conflict reconstruction, Buckland (2005) defines the content and goals of peace education which form the focus of this article. This curricula intervention, he observes, "includes a range of formal and informal educational activities undertaken to promote peace in schools and communities through the 
inclusion of skills, attitudes and values that promote nonviolent approaches to managing conflict and promoting tolerance and respect for diversity" (ibid., 60). This definition captures peace education's concern to promote the inculcation of personal attitudinal and behavioral changes in conflict affected communities (Fountain 1999, 4; Education Above All 2012). Such curricula are also often fused with life skills, citizenship, and human rights education which have similar goals and objectives (Buckland 2005, 60).

This model of peace education has attracted widespread endorsement within the global institutional architecture of aid to conflict affected contexts (Baxter 2001, 2012, 176; UNESCO, UNHCR, and INEE 2005a, 2005b, 2005c; UNESCO 2011, 246). Hence, its circulation across global professional networks and institutional clusters, its promotion by the World Bank, the United Nations Educational, Scientific and Cultural Organization (UNESCO), the United Nations High Commission for Refugees (UNHCR), UNICEF, and INEE, and its celebration in publications for policymakers and practitioners for its special contribution to achieving a "future of peace" in conflict affected contexts (Baxter and Ikbowa 2005, 2). Thus adopted as an exemplary curricula, it has been implemented in very different contexts of conflict targeting diverse constituencies. These range from groups fleeing conflict in their home countries in the refugee camps of northern Kenya and Sudan to teachers and their pupils living in contexts which are affected by or recovering from intra-state conflicts such as Sierra Leone (Bretherton, Weston, and Zbar 2003, 2005; UNESCO 2011, 245 246). Typifying the idealism accompanying this model of peace education is the claim that "if only a fraction of the money spent worldwide on conflict could be spent on peace education programmes like the INEE/UNHCR peace education programme we could achieve a future of peace and hope in refugee communities and postconflict countries around the world" (Baxter and Ikobwa 2005, 2).

However, the institutional success of peace education belies its uncertain and contested emergence within a particular historical conjuncture in the geopolitics of aid and development in the late 1990s. This period was characterized by a major challenge to established development paradigms and practices posed by the re-orientation of aid to conflict-affected states in the 1990s, in which conflict was occurring within rather than between states (Winthrop and Matsui 2013, 17). Extending the sociology of the constituencies who were conflict-affected to include whole populations, including women and children, these new forms of internal conflict created unprecedented strategic and epistemic challenges for those concerned to leverage education for peacebuilding purposes (ibid., 19). Indeed, a re-reading of initial responses by professionals and researchers aiming to mobilize peace education to address new forms of conflict is to be reminded of the equivocation and uncertainty which accompanied their efforts. For instance, Aguilar and Retamal $(1998,139)$ in a UNESCO discussion document in 1998 point out that "the technical impact of education as a tool for 
changing the behaviour and attitudes of an illiterate or semi-literate population affected...in general by the trauma of war needs to be further assessed." Such concerns are in striking contrast to the institutional imprimatur which this model of peace education has subsequently received within the international aid architecture, prompting the particular concerns of this article to problematize its appeal. Indeed, it should be remembered that peace education emerged less from conviction or evidence as to its appropriateness for conflict affected communities than as an experimental and uncertain response of the international aid community to the unprecedented challenge of developing educational interventions that would be relevant for their needs.

Moreover, peace education curricula, aiming to achieve attitudinal and behavioral changes in various conflict affected contexts, have been subject to a range of critiques. Firstly, in relation to its content, scholars have pointed to: its indebtedness to the priorities of the international community rather than context specific conflict analysis (Smith Ellison 2014, 202) or responsiveness to the views and experiences of local grassroots communities (Lauritzen 2016, 320 ); its technical focus on conflict-resolution, involving a "narrow recipe book approach... heavily dependent on workshop training in mediation and negotiation skills" (Bush and Saltarelli 2000, 21); its psychologizing emphasis and foregrounding of the "individual mind" rather than structural issues of social justice and power asymmetries driving conflict (Zembylas and Bekerman 2013, 200); the tendency of its goals to be utopian given its implementation in contexts of structural violence within and outside of schools (Lopes Cardozo 2008); and finally its reputation as a curriculum "based on externally generated and imposed solutions" (Bush and Saltarelli 2000, 26) that belittles or marginalizes the prior "culturally and place specific" (ibid.) exercise of peacebuilding agency amongst local actors in conflict affected contexts. Secondly, in relation to the implementation of peace education, scholars have noted the failure of curriculum developers to anticipate the resistance of teachers, parents, and communities which may impact the sustainability of the attitudinal changes it aims to generate in its target audiences (Salomon 2006). Furthermore, a lack of evidence of its short- or long-term impact (UNESCO 2011, 245) and, thus, its status as an "unevidenced prescription" (Davies 2009, 20) has also been highlighted. Thirdly, and more fundamentally, some have critiqued a lack of reflexivity about the underlying ontological assumptions of peace education by its promoters and practitioners leading to its complicity in "functionalist, psychologised and often idealised perspectives" (Zembylas and Bekerman 2013, 198). Finally, scholars have also noted its narrow social base as an educational project driven by a "largely Northern, white, academic elite" (Bush and Saltarelli 2000, 27).

Mindful of these concerns, some commentators have voiced calls for peace education to reclaim its criticality. For instance, Zembylas and Bekerman (2013, 197) note that as a field of practice and research it needs to eschew a "fideistic 
approach" as well as the "idealism" or "romanticism" which has underpinned its wide application. Consequently, peace education should become "more critical about its theoretical assumptions concerning issues of power relations, social justice as well as the terms of peace and conflict themselves" (ibid.). This case study aims to contribute to this process of constructive critique and revision. The following section outlines the theoretical assumptions and resulting methodology and methods which will enable this more critical scrutiny.

\section{Research Design: Concepts and Methods}

The approach to peace education taken in this article is indebted to the tradition of critical studies on curricula development represented in the work of Apple (1990). Apple has reminded us that the content of educational curricula, understood as providing answers to the question of "what knowledge is of most worth," is never a neutral process. As such, the selection and structuring of knowledge is inherently ideological and political, tied to the operation of asymmetrical power relations and particular interests (Apple 1990, vii). Also relevant are the insights into the operation of such power relations within Western educational projects from the sixteenth century through to colonialism and the present day. Baker (2012) has shown how curricula developed in the West have been deployed in non-Western contexts as key components of a longstanding Eurocentric project to "civilize" humanity through the acculturation of whole populations. Such insights are a reminder of the underlying interests and power relations that may be at stake in processes of curriculum development, however well intentioned.

However, this article draws primarily on the explanatory and heuristic frameworks of a recent cultural turn within political economy analysis, conceived as "cultural political economy" (CPE) (Sum and Jessop 2013). A fundamental ontological premise of a cultural political economy analysis is the inexhaustible complexity of the social world, which therefore necessitates, as an existential necessity, a process of complexity reduction to enable social agents to "go on in the world" (ibid., 24). This insight underpins its analytical concern with how all apprehensions of the social world may be understood as outcomes of various processes of selectivity (ibid., 2-5). Of particular relevance to this article's methodology is discursive selectivity which refers to the social and semiotic production of sense and meaning making in the face of complexity, an exclusionary process in which some construals of reality are privileged over others. This theoretical insight underpins the method adopted in this article through which the content of the Emerging Issues curriculum is interrogated. Applying the notion of complexity reduction therefore invites scrutiny of its representation of the needs of conflict affected Sierra Leoneans targeted for peace 
education not as a neutral construal of social reality but one that privileges, from a range of possibilities, a particular, selective version. A methodological challenge is therefore to highlight the parameters and nature of this portrayal, subjecting to analysis what it includes and, just as importantly, what it excludes.

Also of relevance to this article's research design is the concept of "social imaginary" (Taylor 2004). This term refers to representations of social reality that "frame individual subjects' lived experience of a complex world and inform collective calculation about that world" (Sum and Jessop 2013, 165). Within CPE analysis, social imaginaries are significant in setting "limits to what can be imagined by individual and social agents" (ibid., 204). As such they constitute an important moment of complexity reduction and within CPE analysis function as a heuristic tool through which the process of discursive selectivity may be analyzed. A particular challenge is illuminating and unpacking their "existential assumptions" (Fairclough 2003, 54), an analytical priority that contributes to an understanding of their status as contingent and partial products of processes of meaning making or in other words making sense of the social world.

Applying a CPE framing of social analysis to the representation of social reality of a conflict affected context in a particular peace education curriculum, this article takes a case study approach. This was deemed particularly appropriate as a method that provides an opportunity for in-depth attention to an individual and bounded case, thereby generating rich data for theoretically informed analysis (Yin 2017). Moreover, in selecting as the object of study a peace education curriculum widely perceived by the international aid community as exemplary, this article's sampling strategy was based on the identification of a "paradigmatic" case (Flyvbjerg 2006, 232) which may illuminate issues relevant to other similar curricula.

Aligned with the theoretical foregrounding of complexity reduction in social analysis discussed above, this article focuses firstly on a content analysis of the text of Emerging Issues (EI) curriculum for pre-service teachers (note: similar curriculum texts were produced for pre-service and in-service teachers; this case study refers to the text for distance learners (UNICEF 2008a; 2008b; 2008c)). This study aims to answer the following questions: What are the characteristics and assumptions of the social imaginary through which the EI curriculum represents/ construes conflict affected Sierra Leoneans and the agency of teachers? How may this representation be understood as a partial selection of meaning that excludes alternative possibilities and what is the significance of such exclusions in relation to understanding the contribution of this curriculum to addressing conflict drivers?

Secondly, the article's method draws on CPE's concern to address why some construals are selected and institutionalized over others. Here a key analytical focus is on agential selectivity or, in other words, how the inherent partiality of representations of reality can be understood as the outcome of the actions of 
diverse agents, in which some have more authority and power than others in shaping meanings which are privileged (Sum and Jessop 2013, 162). Hence, the second set of research questions: What are the differential contributions of the diverse actors, national and international, to the process of curricula development of EI understood as a social practice and form of knowledge generation? How do these divergences represent the differential power and status of particular types of knowledge and expertise?

Data collection to answer these questions involved sixteen in-depth, semi-structured interviews with the diverse groups of individuals involved in its development and writing. These included two UNICEF staff directly involved in its production, three other UNICEF educational specialists, two national and international consultants employed to support the processes of curricula development, six lecturers from four teacher training colleges who were involved in writing the curriculum, as well as three individuals from the Ministry of Education who were engaged at different stages in its development. These interviews sought the views of individuals on the process of writing the curriculum and their roles in the production of the final text. In addition, documents related to the origins and development of the EI curriculum were consulted. These included the initial goals envisioned for the curriculum by UNICEF in a concept note prior to the curriculum's development as well as minutes of meetings held to plan the curriculum (UNICEF 2007a; 2007b).

\section{The Sierra Leone Conflict Affected Context, 1992-2018}

Sierra Leone's conflict between 1992 and 2002 resulted in over 50,000 dead, thousands internally displaced, and also left many maimed through the amputation of their arms and legs. Its savagery has lead some commentators to characterize its conflict, in judgemental and moralizing terms, as an irrational descent into primordial barbarism (Kaplan and Rieff 2000) or a manifestation of extreme greed and criminality (Collier et al. 2003). Others (Keen 2005) have emphasized the role of similar socio-economic and political grievances in motivating the violence carried out by all sides in the conflict. Such analyses have highlighted: the alienation and anger of swathes of impoverished, uneducated, and jobless rural youth at their perceived social, political, and economic exclusion by political elites based in Freetown as well as chiefs in rural communities across the country (Richards 1996); massive regional inequalities in the provision of education and health services resulting from a centralization of power and resources in Freetown, a legacy of British colonial rule; resentment at a corrupt and patrimonial style of politics through which elites, through exercising their personal connections, monopolize power and resources; and finally the perceived exploitation of the country's diamond resources by national and international 
actors to benefit a small section of the population. Foregrounding such factors as key explanations for the recourse to violence, the Sierra Leonean conflict has thus been construed as a "venting of grievances and a cry from the dispossessed and powerless who could find no other outlet for their anger and rage at their marginalisation and exclusion in a dysfunctional society" (Hirsch 2006, 305).

Since peace was declared in 2002, Sierra Leone has been the target of various interventions by $\mathrm{UN}$ agencies operating within the priorities of the dominant model of international peacebuilding interventionism: liberal peacebuilding. In particular, establishing security, democracy, and the opening up of markets. Having enjoyed relatively peaceful elections in 2007 and 2012 and one of the fastest economic growth rates in sub-Saharan Africa, largely based on a revival of its mineral extractive industry led by international corporate investment, Sierra Leone is often taken to demonstrate the success of liberal peacebuilding (African Development Bank Group, OECD Development Centre, and UNDP 2017, 287). However, many scholars have also highlighted the continuation of structural drivers of conflict which pose a major threat to sustainable peace. Firstly, they have highlighted the failure of the security and market priorities of liberal peacebuilding to realize the promise that macroeconomic processes of reform would ameliorate the widespread poverty and immiseration of the Sierra Leonean population through a "trickle down" process of wealth redistribution (Castañeda 2009). Secondly, they have noted the failure of the statebuilding mission of international peace operations, oriented more to meeting international goals of global security than to enabling the Sierra Leone state to meet the "everyday" needs and aspirations of its people for improved social services (Cubitt 2013, 92). Thirdly, specific drivers of grievance, especially amongst the population's youth constituency, have been identified. These include lack of job opportunities for youth (Cubitt 2011) and the co-option of youth into political violence by political elites during election times and the continuation of patronage politics (International Crisis Group 2008). Fourthly, researchers have noted resentment in some parts of the country, in particular Kono, at the operation of international mining companies, and a perception that the country's resource wealth is being exploited by global business with little tangible benefits to local populations (Zulu and Wilson 2012). Fifth, there is widespread resentment amongst local mining affected communities at the perceived collusion of elites, local and national, in this process, who are perceived to be monopolizing wealth accruing from such business activity. Finally, continuing widespread distrust and dissatisfaction between the state and its citizens (Drew and Ramsbotham 2012, 60). It is therefore not surprising that many have suggested that Sierra Leone may be considered post-war rather than post-conflict, experiencing only a thin type of negative peace in which many of the causes of grievance and conflict remain unaddressed. Indeed, some commentators have warned of the likelihood of a recurrence of conflict in Sierra Leone (Hanlon 2005; Cubitt 2013). 
This review of recent analysis and evidence of conflict drivers in the Sierra Leonean context has highlighted their complex and multi-dimensional nature with particular implications for this article's focus on the EI peace education curriculum. Firstly, the dynamics of conflict in Sierra Leone are rooted not in identity based ethnic or religious tensions which characterize many contexts targeted by peace education programs, but are driven by inequalities in access to power, resources, and opportunities, in part a legacy of colonial (mis) management of the country. Secondly, they highlight the failures of international peacebuilding interventions since 2002 to address drivers of grievances that underpinned the initial conflict. Thirdly, they are multi-scalar, implicating not only national constituencies of Sierra Leonean elites but international forces, the limitations of the priorities of the UN peacebuilding operations as well as the operations of international mining companies. The presentation of the case study data and the application of a CPE analysis in the following sections will refer back to these insights in order to illuminate the extent to which the EI peace education curriculum engages with the particular contexts and dynamics of conflict which they reveal.

\section{Data Analysis and Findings}

\section{Emerging Issues as an Outcome of Discursive Selectivities}

While addressed to Sierra Leonean pre-service and in-service teachers in 2008, the text of EI (UNICEF 2008a; 2008b; 2008c) is locateable within a genre chain (Fairclough 2003, 31-32) through which attitudinal and behavioral change peace education curricula had been circulated and implemented within institutional networks of international aid agencies in the previous decades. As such, it is striking that large sections of the text repeat verbatim the content of the INEE Peace Education Programme initially developed by the UNHCR and UNESCO for teachers and communities living in refugee camps in Kenya and Uganda between 1997 and 2005 (UNESCO, UNHCR, and INEE 2005a, 2005b, 2005c; Baxter 2012). This was also promoted as developing in its audiences "skills that build positive and constructive behaviours for peace and conflict prevention and minimisation" (Baxter and Ikobwa 2005, 22). Amongst the many areas of direct overlap with the components of the UNHCR programme are EI's text on peace and conflict theory, similarities and differences, trust, honesty, and transparency, communication, questioning skills, effective listening, and the characteristics of an effective teacher. Also reproduced from earlier peace education texts are explanations of the principles of developmental psychology based on Kohlberg, Maslow, and Bloom (UNESCO, UNHCR, INEE 2005a, 23-26; 2005b, 19-22, 30-34, 40-42). This textual strategy therefore appropriates for conflict affected Sierra Leoneans the texts of peace education curricula developed for another 
conflict affected group by other aid agencies, INEE, UNESCO, and UNHCR. The derivative nature of the curriculum's content was recognized by one of its lead writers who noted its alignment with the priorities of its "mother manual," the INEE peace education program (Baxter 2012, 175). "The INEE Peace Education Programme was the foundation of the Emerging Issues programme," Baxter explains, "not least because the basic skills were applicable to human rights, good governance, citizenship and pedagogy" (ibid., 176). Hence, the approach taken in the EI curriculum was to assimilate these areas of content to peace education's overarching goal of "creating a composite and comprehensive whole for the dimension of personal behaviour change" (ibid.).

This derivation of EI from prior peace education and behavior change curricula demonstrates that inter-textual process which Fairclough (2003) refers to as recontextualization, whereby texts and meanings are transferred from one context to another. The resulting verbatim similarities demonstrates how this curriculum's content is explained in part by the institutional embeddedness of peace education as a curricula format transferable across diverse contexts by different international aid agencies. The next section analyzes key themes in the curriculum's content, and in doing so reflects on the consequences of this textual repurposing of a generic peace education format prioritizing attitudinal and behavioral change for its treatment of the singularities of the Sierra Leonean context.

\section{The Representation of Sierra Leoneans}

Explaining the relevance of peace education for Sierra Leoneans, the text declares that " the behaviour and understanding of the people of [Sierra Leone] is not constructive" (UNICEF 2008a, 14). This pathologizing of the nation as a demographic who are to be blamed for their "destructive" behaviors and attitudes, and as such in need of tutelage through peace education, recurs throughout the text. Communicating a particular construal of the character and behaviors of Sierra Leoneans, this amounts to a defining social imaginary invoked throughout the curriculum. At the start of the course, teachers are invited to "think about all the destructive behaviours practised by [Sierra Leone]" (ibid., 7). The nation is variously characterized as endemically corrupt (UNICEF 2008b, 27), self destructive, careless, and lazy in relation to their environment (ibid., 25), culturally deficient in relation to child rearing (UNICEF 2008a, 89) and lacking "genuine respect" for each other (UNICEF 2008c, 10).

This judgemental representation also applies to individual Sierra Leoneans with particular attention to their inner psychological states. Hence EI is presented as a curriculum which will achieve national amelioration through its commitment to the principle that "any change has to come first from within" (UNICEF 2008a, 15), through addressing "behaviour change in individuals" (ibid.). The repetition of verbs such as "internalize" or "instill" (ibid., 18) to characterize the impact of 
curricula content on Sierra Leoneans underscores its focus on the psychological and personal dimension of internal change to remedy purportedly inherent propensities to conflict in the Sierra Leonean demographic.

The text mobilizes several legitimation strategies (Fairclough 2003, 98) to promote and naturalize this social imaginary. It invokes the support of the state and political elites, asserting that the envisaged emphasis on behavioral and attitudinal change responds to the urgent priorities of the President and the Ministry of Education for whom it is "of paramount concern" (UNICEF 2008a, 7). It presents the curriculum in redemptive terms as "life-saving and life-changing" (ibid., 15). It suggests that EI is particularly attuned to the current vicissitudes of the nation and post-conflict renewal. "EI is vital," it declares, "if we are to meet the challenge of living in the [twenty-first] century in a post conflict country that is struggling to rebuild" (ibid., 21). At times the text adopts a moralizing, almost missionary tone in exhorting teachers to reflect on "what we need to understand if we are to be constructive" (ibid., 58) or reminding them that "values are caught not taught" (ibid., 15).

Yet the curriculum's self-righteous language serves to suppress the selective and partial nature of its imaginary of Sierra Leoneans. Indeed, the text's overwhelmingly negative projection distracts attention from the existence of alternative paradigms of the nation and its post-conflict trajectory. For instance, the report of the Truth and Reconciliation Commission (TRC) paid tribute to Sierra Leoneans living "in the ghettoes of Freetown or the villages of the Provinces" who "maintain their dignity notwithstanding conditions of extreme poverty and deprivation," and who are "examples for us all” (SLTRC 2004, vol. $2,125)$. It concluded that "the political elites of successive regimes in the postindependence period were responsible for creating the conditions of conflict" (ibid., 14). Far from representing the behaviors of the whole nation as deficit, the report pinpointed the activities of a small but powerful constituency who "plundered the nation's assets, including its mineral riches at the expense of the national good" (ibid.). This more specific sociology of national failure draws attention to the process of reification and homogenizing of Sierra Leoneans within the framework of the behavior change imperative framing the curriculum text. This results in claims which are highly simplistic when compared with more nuanced contemporary analysis of the causes and nature of conflict in Sierra Leone. Thus, the particular social faultlines within which grievances leading to conflict have emerged and which continue to exist as noted above, between the state and its citizens, urban Freetown elites and rural communities, rural youth and elders (Drew and Ramsbotham 2012), are erased within a broadbrush critique of national misbehaviours. Moreover, recognition of the regional variations in experiences of conflict drivers - as evidenced in a recent nationwide consultation which highlighted land and mining issues in the eastern region of Kono and lack of provision of services in Pujehun in the south-is foreclosed by 
this undifferentiated approach to the national demographic (UNICEF 2011).

The curricula's overwhelming orientation to the need for internal personal change by Sierra Leoneans is also in contradiction with the emphasis of the TRC and others of the persistence into the post-conflict period of the structural drivers of conflict which continue, as noted above, to create misery and frustration for the majority of the population at the time of EI's development. This analysis suggests therefore that the emphasis on the moral failure of Sierra Leoneans as agents of destructive behaviors forecloses attention to the conditions and contexts impacting their everyday lives. As noted above, these include patrimonialism and patronage within national governance and democratic processes, widespread alienation from the state, entrenched rural poverty, limited access to healthcare and education, especially in rural and provincial areas, and mass youth unemployment. Given that some commentators have noted the likelihood of a recurrence of conflict resulting from the persistence of such grievances, the discursive selectivity operating here strikingly indicates the limitations of this curriculum in harnessing education to empower teachers and their pupils to navigate conflict drivers and build a sustainable and "positive" peace.

Justifying its behavioral change program by negative and undifferentiated judgement of the Sierra Leonean demographic, the text's imaginary serves to create the problem for which the attitudinal and behavioral change promised by peace education is the answer. This illustrates that the process of problematization, which Foucault and others have pointed out results from a selective construal of social reality (Sum and Jessop 2013, 202), may serve to secure the naturalization or legitimation of a particular solution, thereby discounting other possibilities. Drawing attention to alternative conceptualizations of the behaviors and attitudes of Sierra Leoneans, this section has highlighted some of the discursive selectivities through which EI presents a highly essentializing and distorted imaginary of conflict affected Sierra Leoneans. The following analysis spotlights other instances of similarly exclusionary processes in its treatment of particular themes and issues.

\section{Human Rights, Civics, and Democracy}

In focusing on the need for individual teachers to understand and to relate their aspirations to the provisions of the 1948 Universal Declaration of Human Rights (UNICEF 2008a, 33, 40) the curriculum's text follows an approach commonplace within the institutionalization of human rights education by the UN (Englund 2000; Coysh 2014). "We will revisit the idea of human rights and the values that they embody," the text declares, "it is these values and the behaviours that reflect them that will be the core of the behaviour change we need for Emerging Issues" (UNICEF 2008a, 41). Coysh $(2014,96)$ points out such framings privilege the "abstract" terms of the legal instrument-understood as the locus of knowledge about human rights to be transmitted to learners over contextually 
rooted understandings and experiences. Given the knowledge we have of what anthropologists have noted is "the role of local social agency in the making of local cultures of human rights in the rural populations of Sierra Leone" (Archibald and Richards 2002, 340), this omission is particularly relevant in the Sierra Leonean context. Recognizing the rootedness of Sierra Leonean experiences of "human rights" in indigenous post-conflict societal transformation, the authors warn that "human rights is not to be understood as the embrace of any preexisting global doctrine of rights, but more as an aspect of local, social renewal, constrained and shaped by wartime experience" (ibid., 340). For instance, a study of post-war social activism among youth in Kono highlights their pursuit of social and economic rights through an interest in collective farming, reform of chiefdom governance, and advocacy against international mining companies. The study makes clear how such aspirations were forged out of their responses to experiences of wartime displacement. These had generated "a new sense of self-reliance among people of all ages," expressed in rejection of traditional modes of unquestioning social deference towards towards chiefs and elders and an intolerance of patrimonial practices (Fanthorpe and Maconachie 2010, 270). Operating outside of the universalizing imperatives conceptualized within UN legal instruments, these insights illuminate how "human rights" behaviors and attitudes are historically rooted within the day to day lived experiences of conflict-affected Sierra Leoneans. Their omission in EI's treatment of human rights demonstrates a discursive selectivity that renders invisible the particular experiences and agency of Sierra Leoneans.

A similar selectivity is evident in the course's treatment of civics and democracy. Here the curriculum makes clear that its overarching concern is a regulatory one to "instill the ideas of democracy in the people of [Sierra Leone]" (UNICEF 2008b, 18). This includes a range of activities aiming to disseminate knowledge amongst the principles and practices of "representative democracy." This approach forecloses recognition of what many commentators have noted is the country's distinctive political culture which renders aspirations to remold Sierra Leonean society "within the norms and institutions of liberal democracy" highly problematic (Taylor 2009, 159-175). Hence particular context-specific features of its political processes, in particular regional and identity politics, clientilism, high stakes elections predicated on competition for the state's resources, and orchestration of youth violence by political elites (International Crisis Group 2008; Cubitt 2013), are bypassed by the overarching framing of Sierra Leone's challenges within generic democratic ideals. Here then is another instance of the decontextualizing effects which result from a process of discursive exclusion that foregrounds peace education's generic focus on individual attitudinal and behavioral changes. 


\section{Local Peacebuilding Agency}

In some instances, what is not mentioned in the text is revealing of the parameters of its social imaginary of conflict affected Sierra Leoneans. For instance, there is no recognition of the work of grassroots, community driven peacebuilding practices such as that of the local NGO Fambul Tok (Drew and Ramsbotham 2012). This organization has been working in communities across the country using traditional practices of conflict resolution through ceremonial bonfires and practices of confession and forgiveness. By ignoring these initiatives, the curricula reproduces that marginalization of grassroots cultural practices of healing and reconciliation which anthropologists and ethnographers have noted was also the weakness of the internationally led transitional justice mechanisms, the TRC, and the Special Court (Shaw 2007). The dominant model of global interventionism, liberal peacebuilding (Richmond 2012, 37), has also been critiqued for its belittling of local agency. In a curriculum devoted to inculcating peaceful behaviors and attitudes addressed to Sierra Leonean teachers and their students, this is a telling omission, suggesting a similar failure to valorize traditional and indigenous approaches to peacebuilding.

\section{The Agency of Teachers}

Teachers are positioned as instrumental in redeeming this national pathology by their role in triggering attitudinal and behavioral change. So the course aims to encourage them to "reflect on the teaching and learning in order to promote the internalising of constructive attitudes and behaviours" (UNICEF 2008a, 7). Moreover, the text locates both teachers and the national community within a narrative of social transformation through peace education which would interrupt and remedy this alleged propensity of Sierra Leoneans to "destructive behaviors." It thus reminds teachers that, in their capacity as behavioral and attitudinal change agents, they are helping to build a new Sierra Leone (ibid., 14), a "better Sierra Leone" (ibid., 46) which will equip the nation to "look to a constructive future" (ibid., 7) and "new ways of doing things" (ibid., 11).

The curriculum's focus on national personal behavior change from a "destructive" base has particular implications for defining the parameters of the agency of teachers which it envisions. Promoted as "change agents" (ibid., 15), they are centralized as pivotal figures in national development, contributing to EI's social imaginary of mass behavior change. The text spells out the particular responsibilities accruing to such a role. In relation to teacher's personal behaviors, it invites them to undertake a continuous process of self-disciplining. "Being a change agent," it cautions, "means understanding that every word you say and every action you take must be consistent with the behaviours you are trying to encourage" (ibid.). Such specification of the responsibilities of teachers emergent from its overarching vision of attitudinal and behavioral change demonstrates what Sum and Jessop $(2013,165)$ have noted is the performative power of social 
imaginaries to "frame individual subjects" lived experience of a complex world and inform collective calculation about that world." EI thus situates teacher agency within a privatized psychological realm of personal and inter-personal behavior change, privileging a narrow understanding of the role of teachers in relation to peacebuilding processes. In effect, this bypasses opportunities to engage them in critical and context-specific analysis of the social injustices and power-relations currently driving grievance and potential conflict in Sierra Leone as noted earlier; and of their potential role in empowering their pupils and the wider communities in which they teach to challenge and transform the status quo as envisaged in other models of peace education (cf. Bajaj and Hantzopoulos $2016,4)$ and more transformative perceptions of teacher agency (Horner et al. 2015, 20-22).

The various exclusions and absences highlighted by this section's analysis of the content of the EI curricula demonstrate the partiality of the social imaginary through which it portrays the needs and agency of conflict affected Sierra Leoneans and their teachers. The next section builds on this analysis of such discursive selectivities by relating them to the contributions of different agents to the production of the final text, thus illuminating the agential selectivities also at work.

\section{The Emerging Issues as an Outcome of Agential Selectivities}

The final text of EI was the outcome of several meetings involving national and international actors over the period between May 2007 and December 2008. These included: (1) an initial consultation in Bo (UNICEF 2007a) involving college principals of five teacher training colleges in Sierra Leone, UNICEF education staff, representatives from the Ministry of Education, the Tertiary Higher Education Commission, and the examinations assessment and awarding body NCTVA (UNICEF 2007b); here the thematic content of EI was agreed to include human rights, civics, and democracy, as well as gender, health, and the environment; (2) arising from the first meeting, the formation of a task force to write the curriculum text which involved lecturers from teacher training colleges (May 2007-June 2008); (3) the submission of the draft texts on the thematic areas to consultants in peace education hired by UNICEF, two international and two national; (4) a process of revision, editing, and making additions to materials under the supervision of the consultants (June-December 2008); and (5) the completion of the final curricula text of 129 sessions (UNICEF 2008a; 2008b; 2008c) characterized by its lead writer and international consultant as a comprehensive program for "personal behavior change" (Baxter 2012, 175).

These processes of curricula production brought together national and international agents, including UNICEF education staff, teacher educators, 
and international peace education consultants. They brought diverse sets of knowledge, expertise, and professional concerns. In particular, this included the educational programming expertise of UNICEF staff, especially in child centred teaching methodologies; the expertise and knowledge of teacher educators and the international expertise in peace education programming and curricula development from the INEE and UNHCR. This collaboration, therefore, had the potential to bring together the local knowledge of Sierra Leonean lecturers with the expertise in peace education of international consultants.

Yet analysis of the documentation linked to the curriculum's textual history as well as insights from interviews with all groups involved in its writing suggests that the final curriculum content, analyzed above, was the outcome of a process of selectivity in which some knowledge was more influential than others in the shaping of the final text. In this regard, it is significant that the curriculum was not initially envisaged as a peace education behavior change program. The initial goal was an attempt to streamline the initiatives of a range of discrete teacher training initiatives by international aid agencies which had proliferated in postconflict Sierra Leone (Baxter 2012, 175; interview with independent consultant). Its original rationale was stated in the "concept note" developed by UNICEF's national staff (UNICEF 2007b). This is also notable for an emphasis on the need to upgrade teacher education to compensate for its lack of engagement with "human rights, democracy and civic education, gender and environmental issues." As "issues of worldwide concern, including Sierra Leone," these were represented as substantive knowledge with global and national significance. In pointing out that "the effects of these issues have resulted in wars, human slavery, maltreatment of people, destruction, violence, abuse of women and children, death and sickness, depletion of human population" (ibid., 2), the concept note also underscored the opportunity presented by the curriculum to equip teachers with substantive knowledge addressing broad multi-scalar societal challenges linked to a range of structural dimensions and symptoms of conflict. That the final text of the EI curriculum foregrounds internal personal attitudinal and behavior changes underscores its departure from this initial broad based vision of teacher empowerment.

Moroever, interviews which invited different groups of participants to share their experience of curriculum writing reveal a process in which the expertise, interests, and knowledge of some participants were privileged over others. This is apparent during the transition from the production of drafts by college lecturers on the agreed thematic issues to be addressed in the curriculum (stage two as outlined above) to the revisions and reshaping into a peace education behavior change framework by national and international consultants of stages four and five. Evoking the extent of the process of textual revision, one independent consultant noted how "the text was transformed from an academic oriented course to behaviour change... a new programme...that change transformed 
the course" (Interview with independent consultant, Freetown, March 2012). Many teacher educators who had written the bulk of the initial texts expressed resentment that their work had not been reflected in the final peace education text. One writer and senior teacher educator commented that "we expected more participation in the writing by our staff" (Interview with senior teacher educator, Freetown, April 2012). Moroever, some expressed caution about the desirability of this form of textual revision, one commenting: "When you bring an external consultant...they look at their experience in other countries...it makes it easier for them...this is what I have done I think it can work here." He added that "what you think may be applicable in one area may not be applicable in another area" (Interview with teacher educator, Freetown, April 2012), underscoring his concern that knowledge brought by independent international consultants may not be relevant to particular contexts.

These insights and reflections demonstrate how the final text of the EI curriculum was a form of knowledge production that relied on several processes of agentic selectivity. Firstly, in foregrounding an inherited peace education format, modelled on pre-existing texts circulating in the international institutional architecture of educational interventions, the textual revisions illustrate what some researchers have noted is a privileging of the "specialized knowledge and techniques" of "experts" in conflict affected contexts (Branch $2011,29)$. In such cases, Kothari $(2005,430)$ points out that "what counts as professional expertise in development is not primarily founded on in depth geographic knowledge about other places and people but is located in technical know how." In the case of the evolution of EI, the problematization of material written by local teacher educators on the thematic content of human rights, civics, and democracy because of its failure to fit with a particular peace education curricula format is a case in point. Moreover, the differential contributions between independent consultants and local writers illustrates a power asymmetry in the process of knowledge production underpinning its final content. It reveals the differential access of participants in EI to certain specialized knowledge-in this case of a generic peace education formula. Within a CPE analysis, this derives from the way some discursive forms, i.e. peace education curricula writing, are "more or less accessible to some agents and not to others because of their sense and meaning making competence" (Sum and Jessop 2013, 215).

Thirdly, the fact that the curriculum was not initially conceived as peace education and only later became so with the involvement of consultants after initial drafts by local writers suggests the power of certain actors to shape and define knowledge production. Bringing the institutional authority accorded to a particular version of peace education in refugee contexts to reframe the EI curriculum in Sierra Leone, the role of the international consultant illustrates how "some agents, by virtue of their nodal position in social networks have better capacities to read particular conjunctures, refocus arguments, displace opponents 
and introduce timely imaginaries and world views than others" (ibid., 220).

\section{Conclusions}

Applying the analytical priorities of cultural political economy to the Emerging Issues curriculum, this case study has attempted to contribute to that process of critically re-envisioning peace education referred to at the start of this article. In so doing, it has revealed some of the limitations and pitfalls of a model of peace education emphasizing attitudinal and behavioral change in conflict affected populations, despite well intentioned aspirations. Several limitations of this curriculum intervention in relation to its capacity to contribute to transformatory peacebuilding have been highlighted in this case study. They serve to caution against the sometimes uncritical idealism which has accompanied the reputation of peace education as a panacea for conflict affected contexts.

First, the findings outlined above reveal the partiality of its content as a form of exclusionary knowledge production that ultimately privileges an international peace education agenda over the context-specific lived realities of its target audiences of teachers, pupils, and local conflict affected communities.

Second and relatedly, by locating the key challenge of peacebuilding in their psyches and personal predispositions, there is a danger of diverting attention from the structural issues of injustice-political, social, and economic-that drove and continues to drive conflict in the country. This psychologizing of conflict forecloses opportunities to harness education to empower conflict affected communities to navigate and address the systemic conditions of hardship and suffering that drive grievances.

Third, there is a danger that the focus of peace education on the need for personal and behavioral change of conflict affected populations may serve a regulatory and disciplinarian agenda that blames them for moral failure. This approach is more aligned with pacification rather than transformation. Jabri (2013, 1) has highlighted the role of pedagogical projects and practices in contributing to the agenda of Western peacebuilding interventions in post-colonial contexts to govern and control their target populations. Indeed its moralistic and homogenizing projection of Sierra Leoneans as a problematic national demographic displaying negative behaviors and requiring social transformation, EI strikingly implicates education within that regulatory and intrusive mission of liberal peacebuilding interventionism "to transform whole societies, including the beliefs and attitudes of their members" (Duffield 2001, 121, 130). In this sense, one of the perhaps unintended consequences of peace education's well intended focus on behavior change is its reiteration of a longstanding Western European agenda to "civilize" other nations through educational interventions.

Fourth, the location of the peacebuilding challenge in the behaviors and 
minds of Sierra Leoneans skews the parameters of conflict analysis not only by inattention to structural violence but also its representation of the national demographic as the locus of the peacebuilding challenges. This delimiting of the geographical parameters of conflict ignores the role of endogenous and global dynamics and their inter-relationship. For instance, in a country where the perceived extractive operations of international mining companies in regional areas are a cause of great frustration to local communities, this curriculum strikingly ignores a major current driver of conflict which implicates actors at multiple scales, international as well as national.

Fifth, the study of the production of EI has highlighted the role of power asymmetries in the process of its production and selection of its content. This draws attention to peace education as a form of knowledge production structured by power relations between international and local actors, an issue overlooked within commentary that assumes its wholly benign and disinterested agenda.

Ultimately, the research evidences how educational interventions can contribute to reinforcing hegemonic narratives that seek to construct violence as pathological and the West as a benign actor reaching out in pursuit of the common good, neither of which stand up to close scrutiny, in Sierra Leone and elsewhere. Sustainable peace, through education and beyond, requires a different narrative that recognizes both our shared humanity and our collective culpability for the drivers of conflict in our increasingly interconnected but highly unequal world.

\section{References}

African Development Bank Group, OECD (Organisation for Economic Cooperation and Development) Development Centre, and UNDP (United Nations Development Programme). 2017. African Economic Outlook 2017: Entrepreneurship and Industrialisation. Paris: OECD.

Aguilar, Pilar, and Gonzalo Retamal. 1998. Rapid Educational Response in Complex Emergencies: A Discussion Document. Geneva: International Bureau of Education.

Apple, Michael W. 1990. Ideology and Curriculum. London and Boston: Routledge \& Kegan Paul.

Archibald, Steven, and Paul Richards. 2002. "Converts to human rights? Popular debate about war and justice in rural central Sierra Leone.” Africa 72 (3): 339-367.

Bajaj, Monisha, and Maria Hantzopoulos, eds. 2016. Peace Education: International perspectives. New York: Bloomsbury Publishing.

Baker, Michael. 2012. "Modernity/coloniality and Eurocentric education: Towards a postoccidental self-understanding of the present." Policy Futures in Education 10 (1): 4-22.

Baxter, Pamela. 2001. "The UNHCR peace education programme: skills for life." Forced Migration Review 11: 28-30.

Baxter, Pamela. 2012. "Development of the INEE peace education programme." In 
Education for Global Citizenship, ed. Education Above All, 165-180. Doha: Education Above All.

Baxter, Pamela, and Vick Ikobwa. 2005. "Peace education: Why and how." Forced Migration Review 22: 28-29.

Branch, Adam. 2011. Displacing Human Rights: War and Intervention in Northern Uganda. Oxford: Oxford University Press.

Bretherton, Diane, Jane Weston, and Vic Zbar. 2003. "Peace education in a post-conflict environment: The case of Sierra Leone." Prospects 33 (2): 219-230.

Bretherton, Diane, Jane Weston, and Vic Zbar. 2005. "School-based peace building in Sierra Leone." Theory into Practice 44 (4): 355-362.

Buckland, Peter. 2005. Reshaping the Future: Education and Postconflict Reconstruction. Washington: World Bank Publications.

Bush, Kenneth David, and Diana Saltarelli, eds. 2000. The Two Faces of Education in Ethnic Conflict: Towards a Peacebuilding Education for Children. Florence: UNICEF.

Castañeda, Carla. 2009. "How liberal peacebuilding may be failing Sierra Leone." Review of African Political Economy 36 (120): 235-251.

Collier, Paul, V.L. Elliot, Håvard Hegre, Anke Hoeffler, Marta Reynal-Querol, and Nicholas Sambanis. 2003. Breaking the Conflict Trap: Civil War and Development Policy. Washington: World Bank.

Coysh, Joanne. 2014. "The dominant discourse of human rights education: A critique." Journal of Human Rights Practice 6 (1): 89-114.

Cubitt, P. Christine. 2011. "Employment in Sierra Leone: What happened to post-conflict job creation?” African Security Review 20 (1): 2-14.

Cubitt, Christine. 2013. "Responsible reconstruction after war: meeting local needs for building peace." Review of International Studies 39 (1): 91-112.

Davies, Lynn. 2009. “Thinkpiece prepared for the Education for All Global Monitoring Report 2011 'The Hidden Crisis: Armed Conflict and Education."' UNESCO, 2011/ ED/EFA/MRT/PI/42. http://unesdoc.unesco.org/images/0019/001907/190778e.pdf (accessed May 3, 2018).

Dilts, Andrew, Yves Winter, Thomas Biebricher, Eric Vance Johnson, Antonio Y. VázquezArroyo, and Joan Cocks. 2012. "Revisiting Johan Galtung's concept of structural violence." New Political Science 34 (2): 191-227.

Drew, Elizabeth, and Alexander Ramsbotham. 2012. "Conclusion: Consolidating peace." Accord: an International Review of Peace Initiatives 23: 60-63.

Duffield, Mark. 2001. Global Governance and the New Wars: The Merging of Development and Security. London: Zed Books Ltd.

Education Above All. 2012. Education for Global Citizenship. Doha: Education Above All.

Englund, Harri. 2000. "The dead hand of human rights: Contrasting Christianities in posttransition Malawi." The Journal of Modern African Studies 38 (4): 579-603.

Fanthorpe, Richard, and Roy Maconachie. 2010. "Beyond the 'crisis of youth'? Mining, farming, and civil society in post-war Sierra Leone.” African Affairs 109 (435): 251272.

Fairclough, Norman. 2003. Analysing Discourse: Textual Analysis for Social Research. London: Routledge.

Flyvbjerg, Bent. 2006. "Five misunderstandings about case-study research.” Qualitative Inquiry 12 (2): 219-245. 
Fountain, Susan. 1999. Peace Education in UNICEF. New York: UNICEF.

Fraser, Nancy. 2005. "Reframing global justice." New Left Review 36: 69-88.

Hanlon, Joseph. 2005. "Is the international community helping to recreate the preconditions for war in Sierra Leone?" The Round Table 94 (381): 459-472.

Hirsch, John L. 2006. "Conflict and Collusion in Sierra Leone, by David Keen. Oxford: James Currey, 2005. 270 pp. £16.95 paperback. ISBN 085255883X.” African Affairs 105 (419): 304-306.

Horner, Lindsey, Laila Kadiwal, Yusuf Sayed, Angeline Barrett, Naureen Durrani, and Mario Novelli. 2015. Literature review: The role of teachers in peacebuilding. http:// www.ungei.org/The-Role-of-Teachers-in-Peacebuilding-Literature-Review-Sept 15. pdf (accessed May 3, 2018).

International Crisis Group. 2008. "Sierra Leone: A new era of reform?" Africa Report No. 143, July 31. https://d2071andvip0wj.cloudfront.net/143-sierra-leone-a-new-era-ofreform.pdf (accessed May 3, 2018).

Jabri, Vivienne. 2013. The Postcolonial Subject: Claiming Politics/Governing Others in Late Modernity. New York: Routledge.

Kaplan, Robert D., and David Rieff. 2000. “The coming anarchy." World Policy Journal 17 (2): 95-96.

Keen, David. 2005. Conflict and Collusion in Sierra Leone. Oxford: James Currey.

Kothari, Uma. 2005. "Authority and expertise: The professionalisation of international development and the ordering of dissent." Antipode 37 (3): 425-446.

Lopes Cardozo, TA Mieke. 2008. "Sri Lanka: In peace or in pieces? A critical approach to peace education in Sri Lanka." Research in Comparative and International Education 3 (1): 19-35.

Lauritzen, Solvor Mjøberg. 2016. "Building peace through education in a post-conflict environment: A case study exploring perceptions of best practices." International Journal of Educational Development 51: 77-83.

Novelli, Mario. 2011. The Role of Education in Peacebuilding: Case Study - Sierra Leone. New York: UNICEF.

Novelli, Mario, and Alan Smith. 2011. The Role of Education in Peacebuilding: A Synthesis Report of Findings from Lebanon, Nepal and Sierra Leone. New York: UNICEF.

Novelli, Mario, Mieke Lopes Cardozo, and Alan Smith. 2015. "A theoretical framework for analysing the contribution of education to sustainable peacebuilding: 4Rs in conflictaffected contexts." Working Paper, UNICEF. http://sro.sussex.ac.uk/58005/ (accessed May 18, 2018).

Novelli, Mario, and Sean Higgins. 2017. "The violence of peace and the role of education: Insights from Sierra Leone." Compare: A Journal of Comparative and International Education 47 (1): 32-45.

Novelli, Mario, and Yusuf Sayed. 2016. “Teachers as agents of sustainable peace, social cohesion and development: Theory, practice \& evidence." Education as Change 20 (3): 15-37.

Richmond, Oliver. 2012. A Post-Liberal Peace. London: Routledge.

Salomon, Gabriel. 2006. "Does peace education really make a difference?" Peace and Conflict: Journal of Peace Psychology 12 (1): 37-48.

Sayed, Yusuf, and Mario Novelli. 2016. The Role of Teachers in Peacebuilding and Social Cohesion: Synthesis Report on Findings from Myanmar, Pakistan, South Africa and 
Uganda. https://www.ulster.ac.uk/__data/assets/pdf_file/0015/224250/role-ofteachers-synthesis-report-final16.pdf (accessed May 3, 2018).

Shaw, Rosalind. 2007. "Memory frictions: Localizing the truth and reconciliation commission in Sierra Leone." The International Journal of Transitional Justice 1 (2): 183-207.

SLTRC (Sierra Leone Truth and Reconciliation Commission). 2004. Witness to Truth: Report of the Sierra Leone Truth and Reconciliation Commission. http://www. sierraleonetrc.org/index.php/view-the-final-report/download-table-of-contents (accessed May 3, 2018).

Sinclair, Margaret. 2004. Learning to Live Together: Building Skills, Values and Attitudes for the Twenty-First Century. Geneva: UNESCO.

Smith Ellison, Christine. 2014. "The role of education in peacebuilding: An analysis of five change theories in Sierra Leone." Compare: A Journal of Comparative and International Education 44 (2): 186-207.

Sum, Ngai-Ling, and Bob Jessop. 2013. Towards a Cultural Political Economy: Putting Culture in its Place in Political Economy. Cheltenham: Edward Elgar Publishing.

Taylor, Charles. 2004. Modern Social Imaginaries. Durham: Duke University Press.

Taylor, Ian. 2009. "Earth calling the liberals: Locating the political culture of Sierra Leone as the terrain for 'reform."' In New Perspectives on Liberal Peacebuilding, eds. Edward Newman, Roland Paris, and Oliver P. Richmond, 159-177. New York: United Nations University Press.

UNESCO (United Nations Education, Scientific and Cultural Organization). 2011. EFA Global Monitoring Report 2011, The Hidden Crisis: Armed Conflict and Education. Paris: UNESCO.

UNESCO (United Nations Education, Scientific and Cultural Organization), UNHCR (United Nations High Commissioner for Refugees), and INEE (Inter-Agency Network for Education in Emergencies). 2005a. Inter-Agency Peace Education Programme: Skills for Constructive Living Teacher Training Manual 1. Paris: UNESCO.

UNESCO (United Nations Education, Scientific and Cultural Organization), UNHCR (United Nations High Commissioner for Refugees), and INEE (Inter-Agency Network for Education in Emergencies). 2005b. Inter-Agency Peace Education Programme: Skills for Constructive Living Teacher Training Manual 2. Paris: UNESCO.

UNESCO (United Nations Education, Scientific and Cultural Organization), UNHCR (United Nations High Commissioner for Refugees), and INEE (Inter-Agency Network for Education in Emergencies). 2005c. Inter-Agency Peace Education Programme: Skills for Constructive Living Background Notes for Facilitators. Paris: UNESCO.

UNICEF (United Nations Children's Fund). 2007a. "Report of the Bo workshop on the enrichment of the teachers certificate curriculum with Emerging Issues." May 8. unpublished.

UNICEF (United Nations Children's Fund). 2007b. "Emerging Issues concept note." unpublished.

UNICEF (United Nations Children's Fund). 2008a. "Emerging Issues resource book Distance Education First Year Modules 1 \& 2."

UNICEF (United Nations Children's Fund). 2008b. "Emerging Issues resource book Distance Education Second Year Modules 3 \& 4." 
UNICEF (United Nations Children's Fund). 2008c. “Emerging Issues resource book Distance Education Third Year Modules 5 \& 6."

UNICEF (United Nations Children's Fund). 2011. "Conflict analysis report.” unpublished.

Winthrop, Rebecca, and Elena Matsui. 2013. A New Agenda for Education in Fragile States. Washington, DC: Center for Universal Education at Brookings.

Yin, Robert K. 2017. Case Study Research and Applications: Design and Methods. Thousand Oaks: Sage publications.

Zembylas, Michalinos, and Zvi Bekerman. 2013. "Peace education in the present: Dismantling and reconstructing some fundamental theoretical premises." Journal of Peace Education 10 (2): 197-214.

Zulu, Leo, and Sigismond Wilson. 2012. "Whose minerals, whose development? Rhetoric and reality in post-conflict Sierra Leone." Development and Change 43 (5): 1103-1131.

Sean Higgins is a Research and Teaching Fellow at the University of Sussex. His research explores the agency of teachers and youth in relation to peacebuilding processes in Sierra Leone. He has also worked on other conflict affected contexts including Myanmar, where he was lead country researcher for a Research Consortium on Education and Peacebuilding funded by UNICEF. He has worked for UNICEF and the International Rescue Committee on teacher education curriculum, development and conflict analysis.

Mario Novelli is Professor of the Political Economy of Education and Director of the Centre for International Education (CIE) at the University of Sussex. His research explores the relationship between education, globalization, and international development, with a specific focus on education delivery in conflict affected contexts. He is currently working on issues related to the role of education in peacebuilding processes and has worked with UNICEF on a series of research projects since 2010. He was Co-director of a major Research Consortium on Education and Peacebuilding, partly funded by UNICEF, between 2014-2016. He has carried out consultancies and research projects for a range of bi-lateral and international organizations including DFID, the Dutch Ministry of Foreign Affairs, UNICEF, and UNESCO. 
